Marquette University

e-Publications@Marquette

6-1-2012

Litigating the "Public Interest" in the Gilded Age: Common Law Business Regulation by NineteenthCentury State Attorneys General

Paul Nolette

Marquette University, paul.nolette@marquette.edu

Accepted version. Polity, Vol. 44, No. 3 (2012) 373-399. DOI. (C) 2012 Palgrave Macmillan. Used with permission. 


\title{
Litigating the "Public Interest" in the Gilded Age: Common Law Business Regulation by Nineteenth-Century State Attorneys General
}

\author{
Paul Nolette \\ Department of Political Science, Marquette University \\ Milwaukee, WI
}

\begin{abstract}
Heeding recent calls to explore the contributions of creative political actors other than federal judges to the process of American legal development, this article examines the role of state attorneys general (SAGs) during the period of rapid industrialization of the late nineteenth and early twentieth centuries. Consistent with recent revisionist accounts concerning the extent of government power during this era of supposed "laissez-faire," I find that SAGs during this period actively and creatively employed ancient common law legal theories in new ways to address the emerging corporate order during this time. Relying on a review of state court cases and newspaper accounts from the period, I examine how SAGs pursued the "public interest" by seeking injunctions against businesses and even corporate dissolution through their use of public nuisance and quo warranto theories. This litigation served as a form of regulation through litigation at a time in which administrative solutions were lacking and also influenced statutory developments during the period.
\end{abstract}

Keywords: state attorneys general, litigation, law, courts, states, American political development 
The Gilded Age of the late nineteenth and early twentieth centuries has been the focus of a long and often contentious line of legal scholarship examining the relationship between American law, politics, and the economy. Overlooking much of this historiography have been the works of Charles Beard, Frank Goodnow, and other early Progressives who argued that a "laissez-faire constitutionalism" exemplified law during the Gilded Age. ${ }^{1}$ In this conception, law and legal institutions fundamentally entrenched liberal laissez-faire economic doctrines during this period, highlighted most clearly by the Supreme Court's infamous 1905 decision in Lochner v. New York. Similarly, scholars such as Morton Horwitz argued that the late nineteenth and early twentieth centuries witnessed the crystallization of "Classical Legal Thought" in American law, embracing ideas compatible with "laissez-faire liberalism" and the "night watchman state." 2 This flowed from the gradual development of the common law in the decades prior to the Civil War, which subsidized private enterprise at the expense of weaker and less organized groups. ${ }^{3}$ Christopher Tomlins argues that there was a shift from the Founding and the early nineteenth century from a democratized ideology of the communal good represented in the discourse of police powers to an emphasis on judge-made common law promoting stability and providing protection from "democratic excess." 4

While this interpretation of law during the Gilded Age dominated post-World War II historical accounts of the era and remains strong in contemporary scholarship, ${ }^{5}$ other scholars have challenged this view. The rethinking of this era began with the work of Charles McCurdy, Alan Jones, and others and has continued to the present. ${ }^{6}$ William Novak, for example, emphasized the importance of the salus populi ("the people's welfare") existing in the early American state. ${ }^{7}$ In a similar vein, Howard Gillman argued that the law of the Lochner Era was not simply a reflection of unrestrained free-market ideology on the part of federal judges, but contained principled distinctions based upon a vision of republican citizenship dating back to the Founders. Gillman notes that courts were concerned not with all regulations, but only those that promoted "class" or partial interests of particular groups rather than the general welfare. ${ }^{8}$ Gerald Berk argued that two distinct paths to industrialization contended during the Gilded Age. The first reflected a laissez-faire corporate liberalism emphasizing the private sphere over the public, but the second was a competing model of

Polity, Vol 44, No. 3 (2012): pg. 373-399. DOI. This article is (C) Palgrave Macmillan and permission has been granted for this version to appear in e-Publications@Marquette. Palgrave Macmillan] does not grant permission for this article to be further copied/distributed or hosted elsewhere without the express permission from Palgrave Macmillan. 
"regional republicanism" that "conceived property and the corporation to be public conventions." According to Berk, law in the late nineteenth century reflected both of these alternative tracks to industrialization. ${ }^{9}$

In the view of these scholars, the American state was stronger and more interventionist than suggested by the assumptions of "laissez-faire" dominance during the Gilded Age. They also suggest that law during the period is best characterized not as a constitutional limit on the growth of the American state, but as a creative and distinctive source of governmental authority. ${ }^{10}$ As Novak argued, "the technologies of American state development and regulation in this period were overwhelmingly legal in nature and in practice," "in contrast to the dominant techniques and strategies of continental European statecraft." Rather than impeding state economic controls, American law provided innovative tools with which to redefine government-business relationships. ${ }^{11}$

This reinterpretation of the role of law during the Gilded Age has occurred alongside a call for scholars to reconsider the judge-focused nature of legal scholarship concerning this period. As Novak put it, legal scholarship has too often "fetishized courts and judges and radically understated the role of other creative lawmakers in the American tradition." 12 A narrow focus on judges threatens to obscure the role of creative and entrepreneurial legal actors who have also had a significant impact on the direction of American legal development.

In this article, I suggest that a closer examination of the important if often underappreciated role played by one set of these entrepreneurial legal actors - state attorneys general (SAGs) - will help to fill in more of the picture of the role of law during the Gilded Age. In particular, the ways in which SAGs mobilized legal authority during the Gilded Age help to illustrate how law could be used as a creative force for stronger and more forceful governmental intervention. It also illustrates that whatever the position of the federal courts - frequently portrayed as largely adopting laissez-faire ideologies - other legal actors at the state level, including SAGs and state judges, were attuned to a republican rather than laissez-faire view of corporate authority. During this period, several SAGs wrestled with the question of how to address the intense public demand for control of the commercial sector while often lacking the express authority to act. Their solution lay in the novel use of their common

Polity, Vol 44, No. 3 (2012): pg. 373-399. DOI. This article is @ Palgrave Macmillan and permission has been granted for this version to appear in e-Publications@Marquette. Palgrave Macmillan] does not grant permission for this article to be further copied/distributed or hosted elsewhere without the express permission from Palgrave Macmillan. 
law powers, which aimed at regulating these new entities in the name of the "public interest."

While the SAGs' innovative use of common law litigation ran into barriers as a way of effectively regulating the emerging national economy of the late nineteenth and early twentieth centuries, their activities during this period are important for several reasons. First, in line with contemporary scholarship, it indicates the creative nature of law during this period. Faced with new problems linked to emerging industrialization and a lack of administrative solutions, SAGs used innovative litigation to pursue regulatory controls on business. Applying old principles of the common law to address new issues, SAGs achieved injunctions against business and dissolution of corporate charters during this time in the name of the public interest. I suggest that this use of the common law served to advance a certain republican conception of government-business relations, in contrast to assumptions of common law as a method of entrenching "laissez-faire" values. The SAGs fit the "public interest" mold particularly well since they were tasked with pursuing the general interest in their litigation, and not merely the special class interests of any particular group. This activity illustrates the common law as reflecting democracy and not simply serving as a tool of industry or as protection against "democratic excess."

Second, this focus on state-level political development fits into Julie Novkov's call for "bringing the states back in" to American political development. ${ }^{13}$ These litigation campaigns illustrate how entrepreneurial political actors used their position to channel political discontent in a way helping influence the development of common and statutory law on the state and federal level. Because of the SAGs' unique institutional position, these state litigators were able to serve as opportunity points for the expression of the "public interest" in the absence of administrative mechanisms or actions by other political institutions. Relying on the common law and using their position as the legal representatives of their state to get into court, these SAGs acted against major business entities in the absence of explicit legislative command or the existence of a strong administrative state. These actions helped to influence legal and statutory development on the state and federal levels.

Third, the actions of SAGs during the Gilded Age help place the high-profile activities of modern SAGs in more historical context.

Polity, Vol 44, No. 3 (2012): pg. 373-399. DOI. This article is (C) Palgrave Macmillan and permission has been granted for this version to appear in e-Publications@Marquette. Palgrave Macmillan] does not grant permission for this article to be further copied/distributed or hosted elsewhere without the express permission from Palgrave Macmillan. 
Several scholars have begun to explore the role of contemporary SAGs, ${ }^{14}$ whose activities have included litigation aimed at regulating tobacco companies, gun manufacturers, polluting energy firms, the lead paint industry, and Wall Street companies. Nevertheless, little scholarship examines the role of SAGs before the modern era. ${ }^{15}$ The modern-day SAGs' use of the common law to regulate business in the face of alleged administrative inaction has an analogue in their predecessors' use of the common law to regulate business entities in a time prior to the full-fledged administrative state. Further, it was during the late nineteenth and early twentieth centuries that the SAGs first realized that pursuing the "public interest" against large corporations required increasing collaboration among themselves, leading to the creation of new mechanisms including the National Association of Attorneys General - an organization that has played a key role in contemporary multistate lawsuits.

\section{The Office of the State Attorney General}

The office of the attorney general traces its origins to medieval England, where the King and other noblemen retained attorneys to handle several governmental tasks. Several of the American colonies established attorneys general early on in their existence, generally retaining the office during the transition from colonies to states. Several states placed the office in state constitutions and, unlike the U.S. Attorney General, the office was transformed from an appointed to elective position in most states beginning in the Jacksonian Era. ${ }^{16}$

The switch in selection method in most states to separate statewide election offered SAGs a level of independence from other state-level political institutions. Their separate statewide election allowed them to be directly responsible to the people as opposed to the governor or the state legislature. This autonomy was particularly important because SAGs were (and are) singly responsible for most or all of their state's legal services. ${ }^{17}$ This ability to independently represent the state's legal interests led one former New York Attorney General, writing just before the start of the New Deal period, to note that because of its place in state government, "the office of the Attorney-General, of necessity, is most intimately associated to the development of the law."18

Polity, Vol 44, No. 3 (2012): pg. 373-399. DOI. This article is (C) Palgrave Macmillan and permission has been granted for this version to appear in e-Publications@Marquette. Palgrave Macmillan] does not grant permission for this article to be further copied/distributed or hosted elsewhere without the express permission from Palgrave Macmillan. 
Most SAGs had broad common law powers inherent to the office that were not specified constitutionally or statutorily and which could be used in the name of the "public interest." 19 As one Maine court stated in the early twentieth century, the attorney general "is clothed and charged with all the common-law powers and duties pertaining to his office." This allowed SAGs to "exercise all such power and authority as public interests may from time to time require, and may institute, conduct, and maintain all such suits and proceedings as he deems necessary for the enforcement of the laws of the states, the preservation of order, and the protection of public rights." 20

The common law powers SAGs retained when colonies became states "were so numerous and varied as to discourage the framers of the state constitutions and legislatures from setting them out in complete detail," thus permitting the SAG to draw upon the long common law traditions of English attorneys general to fill in gaps in their express powers. ${ }^{21}$ Because of the breadth of these common law powers, it is virtually impossible to list them comprehensively. ${ }^{22}$ Nevertheless, several early court cases give an indication of the sort of powers the common law provided. One of the most important of such cases is People v. Miner, a New York state court case decided in 1868. The opinion lists several of the SAGs' traditional common law powers, including the broad ability to prosecute crimes and all actions necessary for the "defense of property and revenues of the crown" as well as specific powers he could use to target other wrongdoing against the sovereign. Because of their application to corporations, I focus on two of these powers for the purposes of this article. Under English common law, attorneys general had the duty: first, "[b]y writ of quo warranto, to determine the right of him who claims or usurps any office, franchise or liberty, and to vacate the charter, or annul the existence of a corporation, for violations of its charter, or for omitting to exercise its corporate powers"; and second, "to prevent public nuisances." 23 Though People v. Miner was a state case from New York, other state courts have frequently cited this enumeration to describe the inherent powers of their respective SAGs. ${ }^{24}$

These common law powers played a particularly important role for SAGs in the latter half of the nineteenth century, as several wrestled with the question of how to best address the emergence of big business during this period. In a foreshadowing of more recent litigation, SAGs applied the common law in new and innovative ways,

Polity, Vol 44, No. 3 (2012): pg. 373-399. DOI. This article is (C) Palgrave Macmillan and permission has been granted for this version to appear in e-Publications@Marquette. Palgrave Macmillan] does not grant permission for this article to be further copied/distributed or hosted elsewhere without the express permission from Palgrave Macmillan. 
providing the legal justification for changes demanded in the name of the "public interest." When courts and limited the possibilities of successful business regulation with one particular common law tool (such as public nuisance), SAGs would turn to others (such as quo warranto) to achieve their regulatory goals.

\section{State Attorneys General in the "Gilded Age"}

As many scholars have documented, post-Civil War America witnessed a number of substantial societal and economic changes, including a tremendous burst of industrialization. The rise of big business during this "Gilded Age" stirred feelings both of pride and anxiety among Americans. ${ }^{25}$ Even as the positive side of economic development led to optimism about future progress, the downsides of rapid business growth led to calls for greater regulation of business.

As Howard Gillman has written, this period was one in which much tension existed between older republican notions and the emerging industrial state. The transformation of the economy began eroding "the assumption about market liberty and republican independence that justified the prohibition against factional or class politics."26 The cherished image of the independent and self-employed artisan or farmer increasingly gave way to the reality of a growing number of Americans employed by others. While government intervention in the economy had been most commonly associated with "the capacity of special interests to interfere" with natural market relations, ${ }^{27}$ the rise of the "new power" of these great corporations prompted a rethinking of the government's role in promoting the public interest.

The role that SAGs could play in helping along this rethinking in this era of the emergence of rapid industrialization was the subject of a particularly interesting decision authored by Judge Edward Ryan of the Wisconsin Supreme Court in Attorney General v. The Chicago and Northwestern Railway Co. (1874). In this case, the Wisconsin Attorney General sued two railroad companies, seeking to prevent them from charging fees in excess of the maximum rates allowed by a statute enacted the same year. The companies replied with several constitutional defenses, including that the statute was a violation of the takings clause, the Contract Clause, and due process under the state and federal Constitutions. Against these individual rights claims,

Polity, Vol 44, No. 3 (2012): pg. 373-399. DOI. This article is @ Palgrave Macmillan and permission has been granted for this version to appear in e-Publications@Marquette. Palgrave Macmillan] does not grant permission for this article to be further copied/distributed or hosted elsewhere without the express permission from Palgrave Macmillan. 
the SAG argued that though the railroads were funded by private investment, they were essentially "public" businesses because the companies' charters were granted by the state legislature, a public body. The charter could be altered and even revoked if abused by the recipient of the charter, because the granting of the corporate charter implied that the corporation must operate consistent with notions of the public interest. Implicit in the SAG's argument was the notion that his office was the appropriate entity to enforce this conception of the railroad companies as "public" companies. ${ }^{28}$

In a lengthy decision, Judge Ryan sided with the attorney general. Relying in part on an analysis of English common law, he noted that the attorney general had the power to act when "any corporation is doing acts detrimental to the public welfare, or hostile to public policy." According to Judge Ryan, the common law of England and America alike now confronted "a new power, unknown to its founders, practically too strong for its ordinary private remedies." This "new power" was the emergence of the great corporations, those "aggregations of capital and power," with influence so large "that few private persons could litigate with them." 29 This change in circumstances warranted the expansion of the common law power of the attorney general to represent the public interest.

Judge Ryan's decision highlights how the growth of corporate power created stress in older notions of what the common law could accomplish and what the public interest required. This new situation demanded greater government oversight of business to ensure that companies were acting in the public interest. As Judge Ryan realized, SAGs could be key players in representing the public interest against the "new power" of the great corporations. And indeed they were, as a number of entrepreneurial SAGs increasingly used the common law as a way to regulate corporations. They took advantage of their position as their state's chief legal officer to counter the downsides of business growth, whether this came in the form of pollution affecting public waters, harmful activities of railroad corporations, or monopolies that worked as "conspiracies against the public."

The SAGs' role as frequent foes of corporate entities in this era occurred before the emergence of full-scale bureaucratization and before the explosion of federal statutes targeting corporate behavior in the twentieth century. The following two sections examine how the SAGs used two common law principles - public nuisance and quo

Polity, Vol 44, No. 3 (2012): pg. 373-399. DOI. This article is (C) Palgrave Macmillan and permission has been granted for this version to appear in e-Publications@Marquette. Palgrave Macmillan] does not grant permission for this article to be further copied/distributed or hosted elsewhere without the express permission from Palgrave Macmillan. 
warranto - to regulate powerful business entities. I chose to pursue my examination in this way because if the SAGs were indeed important political players as Judge Ryan anticipated, then we would expect them to be active against two of the key emerging business entities emerging during the nineteenth century - the railroads and the trusts. A closer look at the period demonstrates that SAGs were indeed active against these entities, using the common law not as a conservative tool for the privileged but as a legal weapon in the fight to maintain public control over rising corporate power.

\section{Public Nuisance as a Regulatory Device}

Several of the earliest suits brought by SAGs to regulate the new business entities relied upon public nuisance theories. Nuisance actions, alleging unlawful use of property causing injury to others, have long been recognized in the common law dating back to twelfthcentury England. English courts recognized early on a distinction between "private" and "public" nuisance. Private nuisance grew out of the law of property, and involved interference with the use of an individual's real property. Public nuisance, by contrast, involved activities interfering with the general rights of the public at large. Unlike its private counterpart, public nuisance was linked with criminal law, allowing public prosecutors to obtain injunctions against activities harmful to the public. Under the common law, it was considerably easier for public prosecutors to bring public nuisance actions than it was for private parties, as any private individual seeking to abate public nuisances was required to show "special injury" separate from general harm to the public before an action could be sustained. Public prosecutors were not subject to this limitation. ${ }^{30}$

William Novak notes that in American law, the "common law of nuisance was one of the most important public legal doctrines of nineteenth-century regulatory governance," reflecting the desire to secure social order and the well-regulated society. ${ }^{31}$ Many of the early examples in which American courts allowed the abatement of a public nuisance involved situations in which persons obstructed public highways or waterways, commonly known as "purprestures." Public nuisance also targeted certain activities offending public morals, such as gambling, prostitution, or the use of profane language. ${ }^{32}$ This usage was similar to how English courts applied public nuisance. ${ }^{33}$

Polity, Vol 44, No. 3 (2012): pg. 373-399. DOI. This article is (C) Palgrave Macmillan and permission has been granted for this version to appear in e-Publications@Marquette. Palgrave Macmillan] does not grant permission for this article to be further copied/distributed or hosted elsewhere without the express permission from Palgrave Macmillan. 
As the enumeration contained in the previously mentioned People v. Miner indicates, the general power to "prevent public nuisances" was recognized in America as one of the several common law powers within the purview of SAGs. The extent of this power, however, was neither specified in any great detail nor subject to clear limitation. As one deputy Attorney General remarked in recent times, "[i]t requires only a little imagination to see the potential use an Attorney General might make of his broad authority to seek abatement of public nuisances." 34 With the onset of industrialization in America, and particularly after the Civil War, several SAGs engaged in efforts to determine how far they could push their power to define a "public nuisance" in the courts. These lawsuits helped regulate private industry at a time in which the administrative state was in an early era of development. As discussed below, SAGs found some level of success using the notion of public nuisance to regulate the growing power of businesses in the name of the "public interest."

SAGs used public nuisance to target an array of business activities in the post-Civil War era. One usage occurred in an area we might now recognize as environmental law. As Noga Morag-Levine documents, the common law of nuisance was used to abate early forms of environmental harms. This often arose in the context of private nuisance, and included such situations as one individual suing his neighbor for damages over the "noxious vapors" escaping from the neighbor's animal pen. ${ }^{35}$ For environmental harms affecting the interests of the public at large, SAG could and did use common law public nuisance theories to enjoin allegedly harmful business activities.

A good example of this usage is the California case of People $v$. Gold Run Ditch and Mining Co. (1884). This case involved a mining company that was found by the SAG to be dumping sand and other material from its mines into two rivers. The SAG sought an injunction preventing the dumping, arguing that the accretion of materials in the rivers threatened the destruction of immense tracts of land and the navigability of the rivers. After the SAG obtained the desired injunction from a lower court, the company appealed, claiming that the injunction was invalid because the mine was simply operating as a legitimate business and had acquired by prescription a private easement to use the river as it pleased. The company also challenged the ability of the SAG to bring this suit in the name of the public interest. The court disagreed with the company's reliance on individual right, noting that

Polity, Vol 44, No. 3 (2012): pg. 373-399. DOI. This article is (C) Palgrave Macmillan and permission has been granted for this version to appear in e-Publications@Marquette. Palgrave Macmillan] does not grant permission for this article to be further copied/distributed or hosted elsewhere without the express permission from Palgrave Macmillan. 
even a "legitimate private business...may grow into a force to threaten the safety of the people" such that it "violates the rights that belong to others." Further, analogizing the river to a public highway, the court held that the river was possessed by the state as a "public trust for the benefit of the people," and it was the purpose of the SAG to enforce these rights on behalf of the public. ${ }^{36}$ As a result, the court sided with the SAG and upheld the injunction prohibiting the company's practices.

SAGs successfully enforced such public rights against private business even when the property being polluted was wholly under private control. In People v. Truckee Lumber Co. (1897), the California Attorney General sought an injunction to prevent a lumber company from depositing wood shavings and other materials into a stream, which had the effect of killing fish in the waters. The company claimed that because it owned the property rights in the stream and the surrounding lands, it was free to do what it wished, as its activities did not involve any public interest. The court dismissed this argument, holding that the pollution did involve the public interest, because the killing of fish (even within wholly private property) affected the availability of public fishing rights in the waters above and below the privately held land. The court relied upon the "universal principle that all property is held subject to those general regulations which are necessary to the common good and general welfare." As in the Gold Run case, the court stressed that the SAG had the power to bring this action on the behalf of the broad public interest, without relying upon a showing that any member of the public in fact had a complaint. ${ }^{37}$

SAGs in other states brought similar successful cases involving what we might now recognize as "environmental law." This included actions restraining an oil company from "wasting natural gas" in its extraction procedures and enjoining an aqueduct company from draining a pond in such a way that would "create and expose upon the shores of said pond a large quantity of slime, mud and offensive vegetation very detrimental to the public health." 38 Because of the absence of a bureaucratic regime empowered to tackle these various emerging environmental problems, these common law public nuisance actions aimed to fill in the resulting "regulatory gap."

In addition to its use as an early regulatory device to address early environmental harms, SAGs sought to use public nuisance to limit the powers of the largest and most prominent industries at the time - the railroads. SAGs were an important and frequent courtroom

Polity, Vol 44, No. 3 (2012): pg. 373-399. DOI. This article is @ Palgrave Macmillan and permission has been granted for this version to appear in e-Publications@Marquette. Palgrave Macmillan] does not grant permission for this article to be further copied/distributed or hosted elsewhere without the express permission from Palgrave Macmillan. 
foe of the railroads in the post-Civil War period, bringing hundreds of lawsuits against the most important national industry at the time. ${ }^{39}$ Several of these cases relied upon common law public nuisance theories to regulate various aspects of the industry.

The use of public nuisance against the railroads, as well as against corporations generally, increased significantly during the last couple of decades of the nineteenth century and into the Progressive Era, eventually declining with the growth of the administrative state in the New Deal period. ${ }^{40}$ A Lexis-Nexis search of state court decisions revealed 106 separate common law public nuisance prosecutions brought by SAGs against railroad corporations from 1865 to $1915 .{ }^{41}$ This number likely underestimates the total number of public nuisance cases SAGs initiated against the railroads, because the Lexis-Nexis database contains only appellate court decisions and neither unappealed lower court decisions nor cases settled out of court. Even this number reveals that SAGs prosecuted a number of cases against the railroads during this period, using theories of public nuisance in the name of the public interest. Moreover, a significant number of these lawsuits were ultimately successful, with SAGs winning just over $60 \%$ of these public nuisance lawsuits against railroad companies.

SAGs representing states across the country employed public nuisance lawsuits against the railroads, led by Kentucky, New Jersey, and Pennsylvania. ${ }^{42}$ The sort of alleged nuisances targeted by SAGs varied widely. Reflecting the earlier uses of public nuisance to abate purprestures, some cases involved railroads allegedly obstructing public highways or waterways in ways constituting public nuisances. ${ }^{43}$ SAGs also used the flexibility inherent in public nuisance to regulate other aspects of the industry as well. The previously noted Wisconsin case of Attorney General v. The Chicago and Northwestern Railway Co. (1874) involved the SAGs' successful attempt to seek an injunction to prevent a railroad from charging fees in excess of the maximum rates allowed by a statute, despite the statute not explicitly allowing the equitable remedy of an injunction. ${ }^{44}$ SAGs in other cases successfully sought to enjoin railroads from charging excessive rates. ${ }^{45}$ Other public nuisance lawsuits alleged that railroad companies were not adequately maintaining their tracks or other structures, ${ }^{46}$ were using freight cars rather than passenger cars on a particular rail line, ${ }^{47}$ had allowed diseased animals from its cattle shipping station to enter the state, ${ }^{48}$ that a train's "smoke from its engines, its ringing of bells, and

Polity, Vol 44, No. 3 (2012): pg. 373-399. DOI. This article is (C) Palgrave Macmillan and permission has been granted for this version to appear in e-Publications@Marquette. Palgrave Macmillan] does not grant permission for this article to be further copied/distributed or hosted elsewhere without the express permission from Palgrave Macmillan. 
its grinding of wheels" constituted a nuisance, ${ }^{49}$ and that a railroad company had willingly allowed people to "engage in dancing, drinking, tippling, cursing, swearing, being drunk, making loud noises and other misbehavior" on land owned by the railroad. ${ }^{50}$

The use of public nuisance in particular was important in these cases in part because, as discussed above, private individuals were restrained in their use of public nuisance to remedy harms done to the public. The common law of public nuisance also provided SAGs the equitable remedy of injunction to restrain business activity, even if existing statutory law allowed only modest fines for violations of their provisions. In Hunt v. Chicago Horse and Dummy Railway Co. (1887), for example, the Illinois Attorney General sought to restrain a railroad company from constructing its railroad in certain streets of Chicago, which the Chicago city council had granted to the companies via an ordinance. The court agreed with the SAG that the city council's action violated a portion of the general (statewide) incorporation act, and held the ordinance void. Importantly, the court held that the Attorney General was empowered to bring this suit based on his power to restrain public nuisances, despite no statute expressly granting him this power. ${ }^{51}$

The public nuisance cases noted in this section help demonstrate one way in which SAGs used the common law to promote the "common good" and the public interest in the face of growing business activities in the 19th century. It was in this latter part of the nineteenth century that courts agreed with the role the SAG claimed in pursuing the "public interest." SAGs were able to pursue claims that essentially constituted an aggregation of private claims, but without the necessity for any particular private entity actually raising any claim. Indeed, because of the limitations courts placed on private lawsuits against public nuisances, SAGs (as well as other public prosecutors in a handful of states) ${ }^{52}$ were the only ones with the ability to do so. The flexibility of the common law of public nuisance could be and was used to regulate and restrain a variety of allegedly harmful corporate behaviors in an era prior to the development of a strong regulatory state.

Many SAGs, however, soon ran up against limitations in of the public nuisance power as a tool to regulate business. As Noga MoragLevine notes, the use of the common law to abate environmental harms became more problematic as those harms multiplied in the age

Polity, Vol 44, No. 3 (2012): pg. 373-399. DOI. This article is (C) Palgrave Macmillan and permission has been granted for this version to appear in e-Publications@Marquette. Palgrave Macmillan] does not grant permission for this article to be further copied/distributed or hosted elsewhere without the express permission from Palgrave Macmillan. 
of rapid industrialization. ${ }^{53}$ Additionally, some courts simply limited the application of public nuisance in certain regulatory contexts. For example, the Supreme Judicial Court of Massachusetts, in Attorney General v. Tudor Ice Co. (1870), rejected the SAG's attempt to bring a public nuisance action against an ice company. The SAG had claimed that the company's trade in non-ice products (including lumber, kerosene oil, and tobacco) went beyond the proper operations of an ice company and thus represented a threat to the public. The court disagreed, holding that since the ice company was a private trading company and "not in any sense a trustee for public purposes," the "acts complained of are not shown to have injured or endangered any rights of the public, or of any individual or other corporation; and cannot, upon any legal construction, be held to constitute a nuisance." 54

For these reasons, public nuisance was not capable of addressing some of the issues arising with the growth of corporations in the later nineteenth century. While public nuisance could be used as a potentially a broad power to regulate the dumping of pollution or the placement of buildings and railroad tracks, it proved incapable of addressing a policy issue that incited great public attention and outcry in the late nineteenth century - regulation of the trusts. SAGs' attempts to do so required them to develop other parts of their common law powers in innovative ways to vindicate the "public interest" against the great private corporations, including the power of quo warranto.

\section{Quo Warranto and the Problem of the Trusts}

The common law power of quo warranto, like public nuisance, traces its roots back centuries to early English law. Under English common law, the king's attorney could issue a writ of quo warranto "against one who usurped or claimed any office, franchise or liberty of the crown, to inquire by what authority he supported his claim, in order to determine the right." A franchise unable to show authority for its exercise was liable to be seized by the king. ${ }^{55}$ This conception evolved both in England and America to include the ouster of individuals unlawfully claiming public office and, most relevant to this discussion, the revocation of corporate charters if the attorney general determined that the corporation abused the charter. ${ }^{56}$

Polity, Vol 44, No. 3 (2012): pg. 373-399. DOI. This article is (C) Palgrave Macmillan and permission has been granted for this version to appear in e-Publications@Marquette. Palgrave Macmillan] does not grant permission for this article to be further copied/distributed or hosted elsewhere without the express permission from Palgrave Macmillan. 
Before the commonplace use of general incorporation statutes, most corporate entities had to receive special charters from their state legislatures in order to carry on business in their state. ${ }^{57}$ This reflected the view that the state's conferral of incorporation on corporations was not simply for private benefit but to further the general welfare and the public interest. Under this republican approach to corporate practice, state officials could use the charter process to monitor corporations and maintain a level of control over their activities. ${ }^{58}$ Through their use of quo warranto proceedings against business entities, SAGs were an important part of this monitoring process, and increasingly so during the period of rapid industrialization following the Civil War.

In the early to mid-nineteenth century, and even through the Gilded Age and into the Progressive Era, most quo warranto actions by SAGs concerned the traditional use of this tool to oust an official from an office held contrary to the law. ${ }^{59}$ However, with the rise of the large corporation during the Gilded Age, coupled with the absence of a strong administrative state able to monitor these entities, SAGs increasingly expanded common law quo warranto proceedings to include corporate defendants. At the heart of these lawsuits were allegations that the defendant corporation had claimed unauthorized privileges or failed to perform activities specified in the charter. The general theory used against corporate entities in these lawsuits rested upon an analogy to the traditional use of quo warranto to oust individuals illegally claiming offices of the crown, with the SAGs claiming that the corporate defendant's action or inaction violated a contract between the holder of the charter and the state. Due to the allegedly injurious nature of this conduct to the public at large, SAGs frequently sought the strictest remedies available under this common law quo warranto action - revocation of the charter and ouster of the corporation from the state. This remedy was thus "one of corporate death," representing "the extreme rigor of the law."60

A Lexis-Nexis search of state court decisions from 1865 to 1915 reveals approximately 400 quo warranto cases brought against corporations over this period. ${ }^{61}$ This search is again likely underestimating the total number of suits initiated by the SAGs by including only resolved appellate court cases not settled out of court, though it provides a good sense of the general use of this tool over this period. Much like their use of public nuisance, SAGs used quo

Polity, Vol 44, No. 3 (2012): pg. 373-399. DOI. This article is (C) Palgrave Macmillan and permission has been granted for this version to appear in e-Publications@Marquette. Palgrave Macmillan] does not grant permission for this article to be further copied/distributed or hosted elsewhere without the express permission from Palgrave Macmillan. 
warranto to target a wide range of alleged corporate wrongdoing. This included suing companies for engaging in business activities beyond those specified in their corporate charters, similar to how the Massachusetts SAG attempted to use public nuisance to prevent an ice company from selling products other than ice. This usage was particularly prevalent in litigation against insurance companies, which often faced SAG litigation accusing them of selling different forms of insurance than specifically authorized by its charter. ${ }^{62}$ SAGs also brought lawsuits against companies for unlawfully collecting tolls on highways or canals, ${ }^{63}$ neglecting duties under corporate charters to provide certain products or services, ${ }^{64}$ failing to reveal corporate information to the state or to maintain adequate capitalization, ${ }^{65}$ charging unreasonable amounts for services rendered such as bank interest or telephone services, ${ }^{66}$ selling intoxicating beverages, ${ }^{67}$ and failing to provide clean water to the public. ${ }^{68}$ In addition to their public nuisance strategy, SAGs employed quo warranto proceedings against the railroads for a variety of alleged wrongdoing. ${ }^{69}$

Quo warranto proceedings were used by SAGs across the country, but particularly so in the Midwest, led by Ohio, Illinois, and Missouri. ${ }^{70}$ Indeed, eight of the ten states most frequently using quo warranto proceedings against corporations during this period were Midwestern states, with only Pennsylvania and Texas among those outside the Midwest. Table 1 indicates the regional variation in the use of quo warranto lawsuits against corporations during this period.

\section{[TABLE 1 HERE]}

That the use of quo warranto to oust corporations from doing business in the state was concentrated in states such as Ohio and Illinois aligns with the general political activism calling for greater business regulation across the Midwest and Great Plains during this period. ${ }^{71}$ Unlike much of the South and in many states further to the west, where calls for business regulation were also strong, these states also contained sizeable industry presence and more opportunity, if not need, for SAGs to use quo warranto procedures. As noted below, Midwestern SAGs, including those of Illinois and Ohio, were particularly prominent in employing high-profile common law quo warranto lawsuits to combat the rise of the trusts in the late nineteenth century.

Polity, Vol 44, No. 3 (2012): pg. 373-399. DOI. This article is @ Palgrave Macmillan and permission has been granted for this version to appear in e-Publications@Marquette. Palgrave Macmillan] does not grant permission for this article to be further copied/distributed or hosted elsewhere without the express permission from Palgrave Macmillan. 
NOT THE PUBLISHED VERSION; this is the author's final, peer-reviewed manuscript. The published version may be accessed by following the link in the citation at the bottom of the page.

Standard Oil attorney Samuel Dodd's invention of the trust device in 1879 was soon to have an explosive impact on American society. ${ }^{72}$ Formally, "trusts" referred to the creation of large holding companies that would purchase the stock of several smaller companies, thus allowing the stockholders to combine capital and control a larger portion of the market. As Dodd himself noted, the term soon took on a wider significance, referring to every act done with the intent to monopolize business, restrain trade, or fix prices. ${ }^{73}$ By 1888 , the New York Times and other leading newspapers blanketed their pages with stories involving the latest growth of a new "trust. "74 The intense public outcry against these aggregations led to frantic efforts to determine how to restrain their power. ${ }^{75}$ There was little consensus among opponents of the trusts as to the best way in which to attack these new entities, but several high-profile and successful actions brought by SAGs demonstrated how the common law tools possessed by these officials, including quo warranto powers, could be used in an attempt to control the trusts. Many of these common-law concepts, developed in large part by attorneys general, found their way into the state and national statutes that created America's early antitrust regime.

In these quo warranto suits, SAGs would claim that trusts usurped powers not granted under their corporate charters, whether these were special charters or issued under general incorporation statutes. Most commonly, SAGs would allege that the charters did not specifically authorize the corporation to buy and hold stock in other companies, and that the power to do so could not be simply implied from a legislative grant to engage in other activities (such as the manufacture and sale of products). ${ }^{76}$ Other quo warranto strategies relied on broader claims that the state incorporation statutes allowed only "the transaction of any lawful business," and that because contracts in restraint of trade were per se unlawful under the common law, the trust went beyond the terms of the incorporation statute. ${ }^{77}$ In these cases, the SAGs sought the remedy of ouster provided by common law quo warranto. While this remedy was "one of corporate death, ${ }^{78}$ SAGs successfully obtained the dissolution of the targeted trust in all of their early quo warranto cases. Table 2 illustrates this by listing the SAG lawsuits against the largest and most notorious trusts during this period.

Polity, Vol 44, No. 3 (2012): pg. 373-399. DOI. This article is (C) Palgrave Macmillan and permission has been granted for this version to appear in e-Publications@Marquette. Palgrave Macmillan] does not grant permission for this article to be further copied/distributed or hosted elsewhere without the express permission from Palgrave Macmillan. 
NOT THE PUBLISHED VERSION; this is the author's final, peer-reviewed manuscript. The published version may be accessed by following the link in the citation at the bottom of the page.

[TABLE 2 HERE]

In the cases against the trusts noted in Table 2, the SAGs used quo warranto proceedings based upon the common law. Using this power, the SAGs were able to convince courts that the trusts, by forming monopolies and restraining competition within their particular industries, had assumed powers "dangerous to the public weal" beyond those granted in their corporate charters. ${ }^{79}$ They did so independently from any distinct legislative or administrative authority to control the trusts, relying instead on the common law.

The identities of the SAGs in these cases against the trusts reflect to some extent the patterns of regional variation in the use of quo warranto generally. The Ohio SAG was the first to bring litigation against Standard Oil, and the SAGs in the Midwestern states of Illinois, Nebraska, and Missouri also prosecuted high-profile actions against trusts. Even so, the use of quo warranto against the trusts in Louisiana, California, and New York indicate that this was not wholly a regional phenomenon. The use of these lawsuits was also not the exclusive province of any one party, as Democratic and Republican SAGs alike brought quo warranto suits against the trusts at this time.

Quo warranto litigation by the SAGs was important in at least a couple of ways. First and most directly, the litigation served as a mechanism for directly regulating the activities of business, including forcing corporate dissolution when the activities were contrary to the public interest. In the early state cases against the trusts, the SAGs achieved a series of high-profile successes. Secondly, SAG activities had an important effect on the development of state and national antitrust policy. Many state antitrust statutes, as well as the Sherman Antitrust Act of 1890 , reflected a reaction to the SAGs' quo warranto cases brought against the trusts beginning in 1887. In fact, several state statutes generally codified the new understandings of antitrust quo warranto by expressly authorizing the SAGs to bring common law antitrust actions. ${ }^{80}$

It comes as little surprise, therefore, that a number of SAGs were active in helping craft the language for these early antitrust statutes. For example, Texas' strongly anti-monopoly Attorney General, James Stephen Hogg, was a key actor in forming the state's anti-trust statute in March 1889. ${ }^{81} \mathrm{His}$ previous experience battling the railroads through a variety of legal techniques led him to emphasize

Polity, Vol 44, No. 3 (2012): pg. 373-399. DOI. This article is @ Palgrave Macmillan and permission has been granted for this version to appear in e-Publications@Marquette. Palgrave Macmillan] does not grant permission for this article to be further copied/distributed or hosted elsewhere without the express permission from Palgrave Macmillan. 
the importance of preventing the formation of a monopoly in its early stages. This was reflected throughout the law as he helped draft the statute's language together with a state legislative committee. Among other things, the statute contained broad language declaring void all contracts in restraint of trade and authorizing the SAG to initiate quo warranto proceedings in the event of a statutory violation. ${ }^{82}$ Several other states enacted statutes codifying the common law of quo warranto as developed in SAG litigation. These new antitrust laws allowed SAGs to file quo warranto actions against trusts, giving statutory backing to actions previously based upon the common law. ${ }^{83}$ As noted below, SAGs continued bringing antitrust litigation in the last decade of the nineteenth century and into the twentieth based upon this statutory codification of their quo warranto powers.

The earliest quo warranto actions of the SAGs against the trusts noted in Table 2 helped influence the debate over the national Sherman Antitrust Act of 1890 as well. As soon as Congress first began consideration of a federal antitrust bill in 1888, proponents of a national statute had to address concerns that the proposed regulations would signal a radical departure from existing law. To help reassure opponents of the bill, including the most prominent critic of the legislation, Senator James Z. George (D-MS), Sherman made the state cases a key part of his defense of the antitrust bill. In his major speech defending the bill on March 21, 1890, as well as in earlier speeches, Sherman argued that his proposal represented a reasonable response to the public outcry over the trusts - and one far preferable to solutions that would be proposed by "the socialist, the communist, and the nihilist" if Congress did not act. ${ }^{84}$ Sherman argued that far from being radical, the proposed act "does not announce a new principle of law, but applies old and well recognized principles of the common law." He continued by noting that the "power of the State courts has been repeatedly exercised to set aside such combinations." 85 Sherman quoted directly from these state cases, including the "very clear and able opinion" of the New York court in the SAGs' case against the Sugar Trust, which Sherman argued set out the rule of the common law. ${ }^{86}$

While Sherman argued that the principles in this litigation were "old and well recognized," the application to the emerging business combinations was in fact novel. By using quo warranto in this new way, the SAGs helped develop the common law and build the

Polity, Vol 44, No. 3 (2012): pg. 373-399. DOI. This article is (C) Palgrave Macmillan and permission has been granted for this version to appear in e-Publications@Marquette. Palgrave Macmillan] does not grant permission for this article to be further copied/distributed or hosted elsewhere without the express permission from Palgrave Macmillan. 
precedent necessary for Senator Sherman to make this claim that "the common law" supported trust-busting. The existence of these state cases helped to provide an appearance of continuity between ancient legal principles and the aims of the Sherman Act, thus giving the Act the appearance of simply codifying existing law, rather than creating a new, far-reaching, or "radical" legal regime.

Additionally, the subsequent history of these state cases bolstered Sherman's contention that federal action against the trusts was necessary. Following the early success of quo warranto litigation against the trusts, the SAGs soon discovered the limits of their ability to effectively use the quo warranto power against business interests. Most importantly, the trusts targeted in this state litigation increasingly took advantage of loose incorporation laws in other states, reorganizing themselves outside the reach of active state prosecutors. ${ }^{87}$ In particular, New Jersey's general incorporation law adopted in 1889 contained the most liberal combination laws in the country, allowing corporations dissolved by state quo warranto actions to simply reorganize themselves as New Jersey corporations. ${ }^{88}$

Sherman noted that because state court decisions were limited to the jurisdiction of their state, they were unable to alone adequately address the problem. State prosecutions could deal with intra-state combinations, but "only the General Government can deal with combinations reaching not only the several States, but the commercial world." 89 The Sherman Act would "supplement the enforcement of the established rules of the common and statute law by the courts of the several States" in addressing combinations engaging in practices against the public interest. ${ }^{90}$ Given that the Sherman Act aimed to "supplement" the states' role, it is not surprising that the SAGs' enforcement powers were generally not preempted under the Sherman Act or subsequent federal antitrust statutes. ${ }^{91}$ The lack of state preemption was important in the years following the Sherman Act because SAGs continued to bring antitrust litigation against trusts based upon new state statutes. This was particularly important after the Supreme Court limited the Sherman Act's application. Following enactment of the Sherman Act, the federal DOJ prosecuted few trusts under the law, a fact opponents of the trusts were quick to point out. ${ }^{92}$ When federal prosecutors did enforce the law, as they did against the American Sugar Refining Company, the U.S. Supreme Court sharply limited the reach of the act. In United States V. E.C.

Polity, Vol 44, No. 3 (2012): pg. 373-399. DOI. This article is @ Palgrave Macmillan and permission has been granted for this version to appear in e-Publications@Marquette. Palgrave Macmillan] does not grant permission for this article to be further copied/distributed or hosted elsewhere without the express permission from Palgrave Macmillan. 
Knight Co. ${ }^{93}$ (1895), the Court held that manufacturing (such as sugar refining) was a local activity that the federal government was unable to regulate under its Commerce Clause power. This interpretation had the practical effect of eviscerating much of the power of the Sherman Act for federal enforcement, with the Court stating that control of the trusts belonged at the state level:

The relief of the citizens of each state from the burden of monopoly and the evils resulting from the restraint of trade among such citizens was left with the states to deal with, and this court has recognized their possession of that power even to the extent of holding that an employment or business carried on by private individuals, when it becomes a matter of such public interest and importance as to create a common charge or burden upon the citizen - in other words, when it becomes a practical monopoly, to which the citizen is compelled to resort, and by means of which a tribute can be exacted from the community - is subject to regulation by state legislative power. ${ }^{94}$

Following E.C. Knight, SAGs became more heavily involved in calling for stronger national legislation and constitutional amendments to deal with the issue. Several statements to this effect were made during the proceedings of the Chicago Conference on Trusts held on September 13-16, 1899, which invited representatives "of all of the leading interests in the different sections of the United States."95 Several SAGs attended and offered speeches, including a scathing address by E.C. Crow from Missouri. Crow excoriated the trusts for standing for "special privileges to the few, and unequal opportunities for the many," arguing that because corporations were but "creature[s] of the state and possessing only the power given it by the state, it should never be able to act or conduct its business as to interfere with the interests of the public." Crow also noted the effect "loose incorporation laws" were having on antitrust enforcement, leading him to argue that "our corporate laws must be remodeled." His chief recommendation was for an assembly of the governors and attorneys general to address this issue together and enact legislation to close these corporate loopholes. ${ }^{96}$ Other SAGs, including the Texas SAG, were more explicit about the necessity for "not only state legislation, but also national legislation" to "remedy the wrong" of the trusts and "protect the right of the people." 97 Referencing E.C. Knight, the Attorney General of Maryland called for amendments to both

Polity, Vol 44, No. 3 (2012): pg. 373-399. DOI. This article is (C) Palgrave Macmillan and permission has been granted for this version to appear in e-Publications@Marquette. Palgrave Macmillan] does not grant permission for this article to be further copied/distributed or hosted elsewhere without the express permission from Palgrave Macmillan. 
federal and state constitutions to allow for anti-trust legislation. ${ }^{98}$ Likewise, the Indiana SAG "look[ed] with confidence to the general control of the entire subject by Congress" since the incorporation "loophole" discovered by the trusts made it impossible for state efforts to address the trust problem fully. ${ }^{99}$

In the meantime, the limitation on the federal power to deal with monopolies announced in E.C. Knight thrust the issue back to the states. SAGs indeed continued to bring quo warranto actions against trusts at and beyond the turn of the twentieth century. ${ }^{100}$ These state cases illustrate SAGs' continuing role as key opportunity points for trust opponents during the period between E.C. Knight and the "trustbusting" administration of Theodore Roosevelt. The beginning of the revival of the Sherman Act during the first decade of the twentieth century was precipitated in part by SAGs, through the initiation of lawsuits against corporations such as the Northern Securities Company (a litigation effort eventually leading to the Supreme Court's decision in Northern Securities Co. v. United States ${ }^{101}$ (1904)) and by forcing federal acknowledgment of the limitations of purely state action against the trusts.

Just as importantly for the SAGs' own institutional development, the problem of the trusts helped lead to greater lines of coordination among these state prosecutors. The increasing prevalence of multistate corporations establishing themselves under general incorporation statutes, and thus avoiding state quo warranto prosecutions, was a major impetus for SAGs to begin coordinating their efforts across state lines. Thirteen attorneys general met in St. Louis in 1907 to discuss issues common to several states, agreeing to establish a permanent national organization to present "a united front...in legal actions brought by different States against the same corporation or trust." 102 Shortly after its creation, this new organization, the National Association of Attorneys General (NAAG), served as a resource for SAGs bringing further actions against the trusts under state antitrust statutes. This included their first ever coordinated lawsuits against Standard Oil during the first decade of the twentieth century. ${ }^{103}$ NAAG remains in existence today and has been a critical resource for modern-day SAGs bringing multistate litigation against corporations in recent years.

The SAGs' use of quo warranto prosecutions against the trusts was one part of a larger political struggle attempting to deal with new

Polity, Vol 44, No. 3 (2012): pg. 373-399. DOI. This article is @ Palgrave Macmillan and permission has been granted for this version to appear in e-Publications@Marquette. Palgrave Macmillan] does not grant permission for this article to be further copied/distributed or hosted elsewhere without the express permission from Palgrave Macmillan. 
issues of rapid industrialization during the Gilded Age and into the Progressive Era involving various state-level and federal actors. SAGs across the country, and particularly in the Midwest, had been increasingly using the common law of quo warranto throughout the Gilded Age as a legal weapon to control business entities alleged to have overstepped their role in promoting the public welfare. With the emergence of the trusts, several SAGs employed this common law tool against monopolies in the absence of existing state or federal statutes to successfully dissolve a number of the largest combinations at the time. Their prosecutions helped develop the common law, creating continuity between "established legal principles" and the new and emerging antitrust regulatory regime being created by state and federal governments.

The use of quo warranto as a means of control of the trusts and other corporations reflected a republican response to the growth of business entities during post-Civil War industrialization. The chief remedy pursued in quo warranto prosecutions - revocation of corporate charters and subsequent "corporate death" - may seem overly harsh to modern eyes, but at the time reflected a regulatory approach viewing corporations as localized entities entrusted with acting consistent with the public welfare. Ultimately, this approach was challenged when, much as with their use of public nuisance, SAGs found that their ability to use the common law to regulate emerging business interests was limited. The use of loose general incorporation laws in states like New Jersey made the individual states' use of quo warranto prosecutions as a means to control the trusts largely ineffective. The SAGs adjusted to this new regime by advocating a larger federal role in antitrust, and in the meantime creating new lines of communication and collaboration between themselves in an effort to present a more united front against the trusts. The SAGs used this collaboration, as well as their now-codified powers under antitrust statutes, to attack the "trust problem" well into the twentieth century.

\section{The Unique Role of the State Attorneys General}

Much as private class action suits often exist parallel to actions brought by state attorneys general in modern times, SAGs' lawsuits were hardly the only actions brought against business interests at the time. A number of private litigators brought actions against trusts, for

Polity, Vol 44, No. 3 (2012): pg. 373-399. DOI. This article is @ Palgrave Macmillan and permission has been granted for this version to appear in e-Publications@Marquette. Palgrave Macmillan] does not grant permission for this article to be further copied/distributed or hosted elsewhere without the express permission from Palgrave Macmillan. 
example. ${ }^{104}$ Nevertheless, the office of the SAG had (and still have) several institutional traits facilitating the role that they played in the development of the law.

For one, the fact that SAGs could rely on common law powers older than the United States itself granted them additional flexibility to pursue emerging policy issues, especially when these common law powers could be employed only by SAGs and not by private litigants. As noted earlier, courts had long recognized a distinction between public and private nuisance. Private litigants could bring actions based upon both legal theories, but the bar for private parties to bring public nuisance actions was placed quite high. As one leading legal treatise in 1893 restated the common law, "no person can maintain an action for damages from a common nuisance where the injury and damage are common to all."105 That private parties needed to prove special damages in public nuisance actions while public parties (particularly SAGs suing in the name of the state) did not meant that the ability to enjoin harms done to the public at large rested largely with SAGs - a legal advantage that SAGs employed frequently.

Likewise, only the state could initiate quo warranto lawsuits under the common law, while private parties could not. This was largely because quo warranto was an extraordinary legal remedy, and its use thus restrained. These proceedings could only be used to pursue the public interest, and could not be used for purely private purposes. A Minnesota case from 1889 expresses a representative view of quo warranto: "As such proceedings are in the nature of a public prosecution, having for their object the recovery to the state of a usurped or forfeited franchise, and not to redress private grievances, no one but the attorney general has authority to institute or prosecute them, it being exclusively for him to determine when public interests require them to be instituted."106

The ability for SAGs to "exclusively" determine whether to use quo warranto aligns with the general notion that SAGs had (and still have) a great deal of flexibility and discretion in choosing the cases to add to their docket. The common law provided a legal resource that did not require express statutory or constitutional delegation, allowing these officials the ability to pursue litigation independently of other actors. One Texas court from 1893 sums up well the reason for allowing SAGs such broad authority - namely, that when private

Polity, Vol 44, No. 3 (2012): pg. 373-399. DOI. This article is @ Palgrave Macmillan and permission has been granted for this version to appear in e-Publications@Marquette. Palgrave Macmillan] does not grant permission for this article to be further copied/distributed or hosted elsewhere without the express permission from Palgrave Macmillan. 
individuals cannot enforce the public interest, the duty to guard the public interest for them falls to the attorney general:

"It is an inherent function of his [the attorney general's] office to protect the public through the courts when they are injured, and have a cause of action. Who else could institute or direct a suit for the public? Can it be said that the courts would be closed to them, and that they would have no remedy against wrong or usurpation, if there should be no express law directing the attorney general to act? When there is a statute directing him, giving a legal remedy, he must be guided by it, but if there be [no statutes] the public are not for that reason deprived of the right to resort to judicial proceedings for protection against wrong." 107

At a time when many viewed the legislatures and governors as incapable of representing the public interest in the face of the political power of business interests, the SAGs' broad common law powers provided an opportunity point for pro-regulatory forces. This was true in states like Ohio and New York, where the state legislatures for time a time declined to enact antitrust legislation. Assisting this role of SAGs as an additional opportunity point was the fact that nearly all SAGs, and indeed all of the SAGs who brought the quo warranto suits against the trusts listed in Table 2, were elected independently from the governors and state legislatures and (unlike the U.S. Attorney General) not under the control of other executive officials. ${ }^{108}$

A number of groups viewed SAGs as potential avenues through which to pursue policy goals. For example, in 1888 , at a time when the emergence of the trusts led to a "thunderous outcry in the press,"109 the New York Times ran a series of editorials urging the New York SAG to act, arguing that his quo warranto powers "should be tested in proceedings against some corporation which has been swallowed up by a Trust." 110 An examination of the leading newspapers during this period suggests that a wide range of groups made applications for the attorney general to take action against business interests, including the Knights of Labor, "disaffected stockholders," small, independent producers urging action against monopolistic trusts, and a New York citizen committee pressuring the SAG to use his quo warranto powers to "force the Manhattan Elevated Railroad Company to provide a seat for every passenger between rush hours, to make the stations sufficiently large for the comfortable accommodation of travelers, and

Polity, Vol 44, No. 3 (2012): pg. 373-399. DOI. This article is @ Palgrave Macmillan and permission has been granted for this version to appear in e-Publications@Marquette. Palgrave Macmillan] does not grant permission for this article to be further copied/distributed or hosted elsewhere without the express permission from Palgrave Macmillan. 
to equip every platform with adequate roofs." 111 Likewise, the Illinois SAG's lawsuit against the Chicago Gas Trust Company noted in Table 2 above followed an application by the Chicago Citizen's Association to sue the trust. ${ }^{112}$

This could act as somewhat of a two-sided coin for SAGs, as those who did not act were often subjects of public comment and criticism. For example, the New York Times noted in 1890 that the Massachusetts SAG's failure to take action against the "offending corporations" was "at last becoming the subject of comment in Boston." The Times goes on to note that the editorial board of the Boston Herald was also beginning to apply pressure on the attorney general, arguing that "the time has now come" for the SAG "to put the machinery of his office in operation for the purpose of testing the matter."113 Much of this criticism arose out of the expectation of the attorney general to act, particularly as "the people [were] to obtain the relief to which they are entitled" only through "official investigation, followed by actions brought in the courts by public prosecutors."114 Because the attorney general had such broad control over the representation of the public interest, much of the attention both positive and negative - focused on his office.

The broad control SAGs maintained over state litigation in turn highlights another structural feature of the SAGs. SAGs maintain a great deal of prosecutorial discretion in handling their caseload, choosing whether or not to bring actions with little interference by other officials. Because "[a]s the representative of the state, an attorney-general is empowered to bring any action which he deems necessary for the protection of the public interests, "115 the SAG has the ability to define the "public interest" such that "as litigator [the SAG] can substantially influence public policy."116 The SAGs' wide discretion allowed them the possibility of resisting public pressure. The Massachusetts SAG mentioned above, for example, opted not to prosecute the trusts despite the public pressure. Likewise, early in the nineteenth century, the Kansas SAG settled with Standard Oil rather than follow the public calls to prosecute, in large measure because of his faith in the American free enterprise system and because he apparently had no desire to punish a leading local industry. ${ }^{117}$

Further, the SAGs' role as public prosecutors allowed them to cloak themselves in an appearance of neutrality even though they were elected, political actors. This recalls political scientist Eugene

Polity, Vol 44, No. 3 (2012): pg. 373-399. DOI. This article is (C) Palgrave Macmillan and permission has been granted for this version to appear in e-Publications@Marquette. Palgrave Macmillan] does not grant permission for this article to be further copied/distributed or hosted elsewhere without the express permission from Palgrave Macmillan. 
Lewis's notion that a key practice by political entrepreneurs is their creation of an "apolitical shield" making their actions appear "to be free of partisanship, greed, self-interest and personal selfaggrandizement. ${ }^{118}$ Ohio SAG David K. Watson, for instance, framed his participation in his lawsuit against Standard Oil as a "matter of duty." As he put it, "I had no personal feeling against the Standard Oil Company, but I meant to enforce the law against it as I would against any other company which I believed to be violating the law." ${ }^{119}$ This cloak of neutrality was important in the context of Ohio state politics at the time, which was dominated on the state level by pro-business Republicans wary of antitrust actions. ${ }^{120}$

Of course, many of Watson's Republican colleagues in Ohio disagreed that this was simply a matter of Watson's "duty" such that he had little choice in the matter. ${ }^{121}$ The same was true of other SAGs who framed their actions as straightforward law enforcement responding to corporate "abuses" or "violations" under law. ${ }^{122}$ Indeed, critics of Democratic New York SAG Charles Tabor labeled his lawsuit against the Sugar Trust a "Tammany Suit" because it allegedly aimed to place pressure on Republicans in the General Assembly to enact antitrust legislation. ${ }^{123}$ An official at the American Smelting and Refining Company accused Colorado SAG C.C. Post, who had just brought quo warranto suit against them, of bringing the suit for "political purposes to curry favor with the Populists." ${ }^{124}$ Yet similarly to judges cloaking themselves in the language of the law, it is easier as a public prosecutor to publicly maintain that the decision to litigate is a simple matter of neutrally "following the law" than it is for a legislator or governor, whose actions are more likely to be seen as mere "political decisions." This dynamic provides a partial explanation for why Watson was able to sue Standard Oil successfully even with the political deck stacked against him. ${ }^{125}$

In short, SAGs during the Gilded Age occupied a unique position as a sort of "pressure release valve" for public anxieties existing concurrent with the rise of large business interests. At a time in which administrative agencies were weak or non-existent, and other political actors had not or would not act, a number of SAGs responded to this public outrage by relying on the tools and advantages inherent in their office. Their electoral independence and wide prosecutorial discretion, as well as their ability to cloak themselves in the neutrality of the law, assisted their ability to act in the "public interest" and to reinforce a

Polity, Vol 44, No. 3 (2012): pg. 373-399. DOI. This article is (C) Palgrave Macmillan and permission has been granted for this version to appear in e-Publications@Marquette. Palgrave Macmillan] does not grant permission for this article to be further copied/distributed or hosted elsewhere without the express permission from Palgrave Macmillan. 
republican notion that the ultimate control of corporate power rightfully resided with the public.

\section{Conclusion}

Throughout the late nineteenth and early twentieth centuries, several SAGs used their unique position to pursue the "public interest" by regulating the activities of the large commercial sector emerging in America's Gilded Age by means of innovative common law litigation. This activity evolved with changing circumstances throughout the nineteenth century, as SAGs sought to achieve business regulation through public nuisance theories, and, with the emergence of the trusts, to vindicate the "public interest" by using quo warranto powers against the trusts.

The SAGs' litigation during this time was important for a number of reasons. For one, the SAGs' pursuit of the "public interest" during this era serves as a partial corrective to the notion that the law during the nineteenth century chiefly reflected governments' wish to enhance the economic interests of private actors. As employed by SAGs, the common law served not as a barrier to "democratic excess," but as an expression of the public's interest vis-à-vis the great corporations. Contrary to bolstering liberal "laissez-faire" ideologies, this common law regulation through litigation reflected a certain republicanism in viewing the rightful role of corporations as expressions of the public interest. To that end, SAGs were willing to use injunctions and even seek "corporate death" through quo warranto if corporations abused their role.

The SAGs' common law litigation also highlights an underappreciated way in which entrepreneurial actors could seek stricter regulation of corporations at a time in which administrative solutions were largely unavailable. Several of the perceived social ills targeted by the SAGs' litigation - environmental harms, the "trusts", problems caused by the railroads - faced regulatory controls weaker than that demanded by key elements of the public. While proregulatory forces pushed for a stronger regulatory state to address these emerging issues of industrialization, they simultaneously looked to other avenues to potentially achieve these goals. SAG common law litigation was one such avenue available to fill the widening "regulatory gaps" during this period. As state actors clothed with electoral

Polity, Vol 44, No. 3 (2012): pg. 373-399. DOI. This article is @ Palgrave Macmillan and permission has been granted for this version to appear in e-Publications@Marquette. Palgrave Macmillan] does not grant permission for this article to be further copied/distributed or hosted elsewhere without the express permission from Palgrave Macmillan. 
independence from other state political institutions and the ability to represent the state in litigation, SAGs provided a promising avenue for a public demanding action, even if other institutions seemed to be turning a deaf ear. SAGs such as Ohio's David Watson were able to use their institutional advantages to channel public outrage against the "trusts" even in the context of institutional hostility.

While the SAGs' efforts to use the common law in this way often ran into limitations, their litigation often achieved at least short-term success in court. Further, the SAGs' efforts to develop the common law had an influence on the development of state and national antitrust policy, providing a precedent for the government's role in attacking trusts. In this way, SAG common law litigation served as an important bridge between existing regulatory gaps and the more systematic regulatory state that emerged in the Progressive Era and New Deal period.

The regulatory "gap-filling" role of this early SAG common law litigation also helps to place the role of modern-day SAGs in greater context. Initially, with the creation of the federal and state administrative state and the explosion of statutory law that occurred in the twentieth century, the SAGs' use of the common law to regulate business dwindled. ${ }^{126}$ In more recent times, however, these state public prosecutors have revived common law litigation. Recently, for example, SAGs have used common law public nuisance theories to tackle a variety of public harms not explicitly regulated by statute or administrative regulation. The most prominent recent litigation campaign involved the numerous SAG lawsuits targeting the nation's largest tobacco firms in the late 1990s, which ultimately ended in a massive $\$ 200+$ billion settlement containing new regulations on the industry and involving nearly all the nation's SAGs. ${ }^{127}$ Among other causes of action in this litigation, SAGs included claims for public nuisance, arguing that the tobacco companies' marketing and distribution practices "intentionally and unreasonably interfered with the public's right to be free from unwarranted injury, disease and sickness, and have caused damage to the public health, the public safety and the general welfare of the citizens." 128 While having a significant impact on national tobacco regulation, this effort occurred in the face of congressional and administrative inaction on the issue. SAGs have also used public nuisance theories to tackle problems of climate change left largely unaddressed by Congress, attempting to

Polity, Vol 44, No. 3 (2012): pg. 373-399. DOI. This article is @ Palgrave Macmillan and permission has been granted for this version to appear in e-Publications@Marquette. Palgrave Macmillan] does not grant permission for this article to be further copied/distributed or hosted elsewhere without the express permission from Palgrave Macmillan. 
gain injunctions against power plants emitting large amounts of carbon dioxide into the atmosphere. ${ }^{129}$ Other recent SAG uses of common law public nuisance theories include lawsuits against manufacturers of firearms and lead paint. ${ }^{130}$

In these cases, as with the public nuisance cases of their predecessors in the Gilded Age, SAGs have used the common law to address emerging public issues when administrative or legislative approaches to tackling these problems had not been implemented. For Gilded Age SAGs, public nuisance served as a regulatory tool in the era before the fully developed post-New Deal administrative state. For contemporary SAGs, public nuisance has served as a regulatory device when other political actors - such as Congress or the Environmental Protection Agency - had declined to regulate certain alleged harms.

Unlike public nuisance, which has witnessed a renaissance among SAG litigants in recent years, the common law tool of quo warranto is no longer an important part of the SAGs' legal repertoire. As noted above, several states codified in their antitrust statutes the SAGs' early use of quo warranto to attack monopolies, but the use of quo warranto generally left usage largely because the emergence of loose general incorporation statutes made the use of this extraordinary legal remedy impractical, and because the chief legal remedy associated with quo warranto - revocation of corporate charters and subsequent "corporate death" - was viewed as too blunt a weapon.

However, the SAGs' use of quo warranto in antitrust prosecutions played a role in the SAGs' own institutional development, as the difficulty of the SAGs' early antitrust regime to control the trusts led to the SAGs modernizing their own legal mechanisms. The SAGs' formation of the National Association of Attorneys General was precipitated by the long-term ineffectiveness and inefficiencies of single-state prosecution of the trusts. Through this new organization, the SAGs combined efforts against the trusts and other corporate entities, thus avoiding duplication and allowing better legal coordination against corporate enterprises increasingly operating across state lines. NAAG still exists today as a forum for SAG collaboration and has been critical in coordinating recent litigation initiated by SAGs, including those modern-day campaigns noted above. ${ }^{131}$

State attorneys general were among the many actors during the late nineteenth and early twentieth centuries helping to craft legal and

Polity, Vol 44, No. 3 (2012): pg. 373-399. DOI. This article is @ Palgrave Macmillan and permission has been granted for this version to appear in e-Publications@Marquette. Palgrave Macmillan] does not grant permission for this article to be further copied/distributed or hosted elsewhere without the express permission from Palgrave Macmillan. 
political development during this key era of industrialization. Scholars exploring political development during this period should consider the role of public prosecutors, along with state judges, legislatures, and private interest groups, in this development. Particularly as modernday SAGs make headlines with their "regulation through litigation" in areas from tobacco policy to global warming, the actions of SAGs during the late nineteenth and early twentieth centuries serve as a reminder that government prosecutors' use of litigation to regulate business has roots tracing back to the early days of American industrialization.

\section{Notes:}

${ }^{1}$ Charles Austin Beard, Contemporary American History, 1877-1913 (New York: Macmillan Co., 1914); Frank J. Goodnow, Social Reform and the Constitution (New York: Macmillan Co., 1911).

2 Morton J. Horwitz, The Transformation of American Law, 1870-1960 (New York: Oxford University Press, 1992), 19-20.

3 Morton J. Horwitz, The Transformation of American Law, 1780-1860 (Cambridge, MA: Harvard University Press, 1977), 100-101.

${ }^{4}$ Christopher L. Tomlins, Law, Labor, and Ideology in the Early American Republic (New York: Cambridge University Press, 1993), 95, 105.

${ }^{5}$ William Novak makes this point in William J. Novak, "Law and the Social Control of American Capitalism," Emory Law Journal 60 (2010): 380381. For a recent example illustrating the strength of this interpretation in contemporary scholarship, see Jed Handelsman Shugerman, "Economic Crisis and the Rise of Judicial Elections and Judicial Review," Harvard Law Review 123 (2010): 1061.

${ }^{6}$ Charles W. McCurdy, "The Knight Sugar Decision of 1895 and the Modernization of American Corporation Law, 1869-1903," Business History Review 53 (1979); Alan Jones, "Thomas M. Cooley and "Laissez-Faire Constitutionalism": A Reconsideration," Journal of American History 53 (1967). These and related revisionist literature is well summarized in Stephen A. Siegel, "The Revision Thickens," Law and History Review 20 (2002).

7 William J. Novak, The People's Welfare: Law \& Regulation in NineteenthCentury America (Chapel Hill: University of North Carolina Press, 1996).

${ }^{8}$ Howard Gillman, The Constitution Besieged: The Rise and Demise of Lochner Era Police Powers Jurisprudence (Durham, NC: Duke University Press, 1993), 26, 29, 55.

Polity, Vol 44, No. 3 (2012): pg. 373-399. DOI. This article is (C) Palgrave Macmillan and permission has been granted for this version to appear in e-Publications@Marquette. Palgrave Macmillan] does not grant permission for this article to be further copied/distributed or hosted elsewhere without the express permission from Palgrave Macmillan. 
NOT THE PUBLISHED VERSION; this is the author's final, peer-reviewed manuscript. The published version may be accessed by following the link in the citation at the bottom of the page.

${ }^{9}$ Gerald Berk, Alternative Tracks: The Constitution of American Industrial Order, 1865-1917 (Baltimore: Johns Hopkins University Press, 1994), 13-14.

10 Novak, "Law and the Social Control," 378.

11 Ibid., 391.

12 William J. Novak, "A State of Legislatures," Polity 40 (2008): 341.

13 Julie Novkov, "Bringing the States Back In: Understanding Legal Subordination and Identity through Political Development," Polity 40 (2008): 24-48.

${ }^{14}$ See Cornell Clayton, "Law Politics, and the New Federalism: State Attorneys General as National Policymakers." Review of Politics 56 (1994); Colin Provost, "The Politics of Consumer Protection: Explaining State Attorney General Participation in Multi-State Lawsuits," Political Research Quarterly 59 (2006).

15 The best single resource on the general history of SAGs is a publication by the National Association of Attorneys General, though this is a largely descriptive work. See Emily Myers and Lynne Ross, eds., State Attorneys General: Powers and Responsibilities, 2nd ed. (Washington D.C.: National Association of Attorneys General, 2007). Some scholars have examined the historical development of individual SAG offices. See, for example, Scott Van Alstyne and Larry J. Roberts, "The Powers of the Attorney General in Wisconsin," Wisconsin Law Review 1974 (1974): 721-750. Others have noted the existence of state litigation against business in the Gilded Age, though not with a specific focus on the institutional role of the SAGs in this litigation. See McCurdy, "The Knight Sugar Decision"; Hans B. Thorelli, The Federal Antitrust Policy: Origination of an American Tradition (Baltimore: Johns Hopkins Press, 1954).

16 Hugh H. L. Bellot, "The Origin of the Attorney General," Law Quarterly Review 25 (1909): 403; John A. Fairlie, "Law Departments and Law Officers in American Governments," Michigan Law Review 36 (1938): 908; Lynne M. Ross, ed., State Attorneys General: Powers and Responsibilities (Washington, D.C.: The Bureau of National Affairs, Inc., 1990), 19.

17 Ross, State Attorneys General, 11.

18 John J. Bennett, Jr., "The Development of the Law As Seen in the Office of the Attorney-General," Brooklyn Law Review 1 (1932): 64.

19 National Association of Attorneys General, Common Law Powers of State Attorneys General (Raleigh, N.C.: Committee on the Office of Attorney General, 1977), 22-23.

20 Withee v. Lane \& Libby Fisheries Company, 120 Me. 121, 123 (1921).

${ }^{21}$ John Ben Shepperd, "Common Law Powers and Duties of the Attorney General," Baylor Law Review 7 (1955): 1; Rufus L. Edmisten, "The

Polity, Vol 44, No. 3 (2012): pg. 373-399. DOI. This article is (C) Palgrave Macmillan and permission has been granted for this version to appear in e-Publications@Marquette. Palgrave Macmillan] does not grant permission for this article to be further copied/distributed or hosted elsewhere without the express permission from Palgrave Macmillan. 
Common Law Powers of the Attorney General of North Carolina," North Carolina Central Law Journal 9 (1977): 35.

22 State v. Boeckler Lumber Co., 302 Mo. 187, 206 (1924) ("The duties of the Attorney-General at common law were so varied and numerous that they have perhaps never been specifically enumerated").

23 People v. Miner, 2 Lansing (N.Y.) 396, 398-399 (1868).

24 See, e.g., Attorney General v. Chicago and Northwestern Railway Co., 35 Wis. 425, 1874 Wisc. LEXIS 135 (1874).

25 For example, see Charles W. Calhoun, ed., The Gilded Age: Perspectives on the Origins of Modern America (Lanham, MD: Rowman \& Littlefield Publishers, Inc., 2007).

26 Gillman, The Constitution Besieged, 63.

27 Ibid., 26.

${ }^{28}$ Attorney General v. Chicago and Northwestern Railway Co., 35 Wis. 425, 1874 Wisc. LEXIS 135, 168 (1874).

29 Ibid., 168-169, 175.

30 Joseph Joyce and Howard Joyce, Treatise on the Law Governing Nuisances (Albany, NY: M. Bender \& Co., 1906), §14.

31 Novak, The People's Welfare, 60.

32 Donald G. Gifford, "Public Nuisance as a Mass Protects Liability Tort," University of Cincinnati Law Review 71 (2003): 800-801.

33 William Blackstone, Commentaries on the Laws of England: A Facsimile of the First Edition of 1765-1769, vol. 4 (Chicago: University of Chicago Press, 1979), 167.

34 Arlen C. Christensen, "The State Attorney General," Wisconsin Law Review 1970 (1970): 319.

35 Noga Morag-Levine, Chasing the Wind: Regulating Air Pollution in the Common Law State (Princeton, NJ: Princeton University Press, 2003).

36 People v. Gold Run Ditch and Mining Co., 66 Cal. 138, 145, 151-152 (1884).

37 People v. Truckee Lumber Co., 116 Cal. 397, 402 (1897).

38 State v. Ohio Oil Co., 150 Ind. 21 (1898); Attorney General v. Jamaica Pond Aqueduct, 133 Mass. 361 (1882).

39 For example, a Lexis-Nexis search revealed nearly three thousand lawsuits brought by the state against railroad companies in the fifty years following the Civil War (1865-1915). This number is approximate, since the search terms used were blunt: [((name(railroad or railway) and name(state or commonwealth or people or "attorney general"))]. However, this gives some indication of the significant number of lawsuits SAGs brought against the railroads during this time.

40 Gifford, "Mass Products Liability Tort," 805-806.

41 The following terms were used in this Lexis-Nexis search of the years 1865 to 1915: [("public nuisance" or "common nuisance") and

Polity, Vol 44, No. 3 (2012): pg. 373-399. DOI. This article is @ Palgrave Macmillan and permission has been granted for this version to appear in e-Publications@Marquette. Palgrave Macmillan] does not grant permission for this article to be further copied/distributed or hosted elsewhere without the express permission from Palgrave Macmillan. 
(((name(state or people or "attorney general")) or counsel("state of Alabama" or "attorney general" or "atty. general" or "attorney gen." or "atty. gen." or "atty.-gen." or "attorney gen."))] I used this search for each jurisdiction, replacing the name of the appropriate state in the search and "commonwealth" rather than "state" when appropriate. I then made note of each case that was brought against a railroad.

42 The most active were Kentucky (23 cases), New Jersey (17), Pennsylvania (11), Illinois (9), and New York (8).

43 See State v. Grand Trunk Railway of Canada, 59 Me. 189 (1871); AttorneyGeneral v. Delaware and Bound Brook Railroad Co. 27 N.J. Eq. 1 (1876); People v. New York, New Haven, and Hartford Railroad Co., 89 N.Y. 266 (1882).

${ }^{44}$ Attorney General v. Chicago and Northwestern Railway Co., 35 Wis. 425 (1874).

45 See, for example, State v. Boston \& Maine Railroad, 75 N.H. 327 (1909).

46 Louisville, Henderson \& St. Louis Railway Co. v. Commonwealth, $144 \mathrm{Ky}$. 625 (1911) (involving a failure to provide a "suitable and convenient water closet"); Attorney General v. North Jersey Street Railway Co., 54 N.J. Eq. 263 (1896) (involving the placement of poles and wires associated with an electric street railway).

47 Attorney General v. Chicago and Evanston Railroad Co., et al., 112 Ill. 611 (1884).

48 State v. Missouri Pacific Railway Co., 71 Kan. 613 (1905).

49 Louisville \& Nashville Railroad Co. v. Commonwealth, 158 Ky. 773 (1914).

50 Commonwealth v. Cincinnati, New Orleans \& Texas Pacific Railroad Co., 139 Ky. 429 (1908).

51 Hunt v. Chicago Horse and Dummy Railway Co., 121 Ill. 638, 649 (1887). Though the Illinois Supreme Court reversed the lower court in this case, the Supreme Court adopted the lower court's analysis of the power of the attorney general to bring this suit in a note to its full opinion.

52 In Illinois, for example, each county's State's Attorney had the power to bring quo warranto actions in addition to the Attorney General. See, for example, People, ex rel. Charles S. Deneen, State's Attorney v. The People's Gas Light and Coke Company, 205 Ill. 482 (1903).

53 Morag-Levine, Chasing the Wind, 57. This was in reference to the use of common law to control industrial pollution in England, but similar limits on the common law in America also existed.

${ }^{54}$ Attorney General v. Tudor Ice Co., 104 Mass. 239, 240-241 (1870).

55 James L. High, A Treatise on Extraordinary Legal Remedies, 3rd ed.

(Chicago: Callaghan \& Co., 1896), §592-§593.

56 Chester James Antieau, The Practice of Extraordinary Remedies (New York: Oceana Publications, 1987), §4.07.

Polity, Vol 44, No. 3 (2012): pg. 373-399. DOI. This article is (C) Palgrave Macmillan and permission has been granted for this version to appear in e-Publications@Marquette. Palgrave Macmillan] does not grant permission for this article to be further copied/distributed or hosted elsewhere without the express permission from Palgrave Macmillan. 
57 Lawrence Meir Friedman, A History of American Law, 3d ed. (New York: Touchstone, 2005), 129-135.

58 David Scuilli, Corporations vs. the Court: Private Power, Public Interests (Boulder, CO: Lynne Rienner, 1999), 91.

59 To take one of hundreds of potential examples, see State ex rel. AttorneyGeneral v. Gilbreath, 48 Mo. 107 (1871) (involving the Missouri SAG's use of quo warranto to oust a justice of a county court).

60 People v. North River Sugar Refining Co., 121 N.Y. 582 (N.Y. 1890).

61 The following terms were used in this Lexis-Nexis search of the years 1865 to 1915: ["quo warranto" and ((name(state or people or "attorney general")) or counsel("state of Alabama" or "attorney general" or "atty. general" or "attorney gen." or "atty. gen." or "atty.-gen." or "attorney gen."))]. I proceeded with a search of each jurisdiction as I did above (see note 41). Because the search results included many quo warranto cases brought against individuals to remove them from office, I included in my case count only those cases brought against corporations, not including cases in which "quo warranto" appeared in the language of the opinion only in passing.

62 State v. Aetna Life Insurance Co., 69 Ohio St. 317 (1904). Also see Ohio v. Interstate Savings Investment Co., 64 Ohio St. 283 (1901); State v. Fidelity \& Casualty Insurance Co., 39 Minn. 538 (1888); State v. Manufacturer's Mutual Fire Insurance Co., 91 Mo. 311 (1886); State v. Vigilant Insurance Co. of Nimrod, 30 Kan. 585 (1883).

63 Attorney General v. Detroit \& Saline Plank Road Co., 97 Mich. 589 (1893); People v. Lake Superior Ship Canal, Railroad \& Iron Co., 32 Mich. 233 (1875).

64 State v. Twin Village Water Co., 98 Me. 214 (1903); State v. Washington Steam Fire Co. No. 3, 76 Miss. 449 (1898); People v. Plymouth Plank Road Co., 31 Mich. 178 (1875).

65 State v. Park \& Nelson Lumber Co., 58 Minn. 330 (1894); State v. Nebraska Home Co., 66 Neb. 349 (1902).

${ }^{66}$ State v. Boatsmen's Savings Inst., 48 Mo. 189 (1871); State v. Toledo Home Telephone Co., 72 Ohio St. 60 (1905).

67 See, for example, State v. Missouri Athletic Club, 261 Mo. 576 (1914).

68 Commonwealth v. Potter County Water Co., 212 Pa. 463 (1905).

69 Attorney General v. Erie \& Kalamazoo Railroad Co., 55 Mich. 15 (1884); State v. Duluth Street Railway Co., 128 Minn. 314 (1915); State v. Sioux City \& Northern Railroad Co., 43 Minn. 17 (1890); State v. Chicago, Burlington \& Quincy Railroad Co., 25 Neb. 156 (1888).

70 The regions noted in Table 1 include the states in the four main census regions used by the U.S. Census Bureau. Ohio conducted 62 quo warranto cases against business in this period, followed by Missouri (59) and Illinois (41).

Polity, Vol 44, No. 3 (2012): pg. 373-399. DOI. This article is (C) Palgrave Macmillan and permission has been granted for this version to appear in e-Publications@Marquette. Palgrave Macmillan] does not grant permission for this article to be further copied/distributed or hosted elsewhere without the express permission from Palgrave Macmillan. 
NOT THE PUBLISHED VERSION; this is the author's final, peer-reviewed manuscript. The published version may be accessed by following the link in the citation at the bottom of the page.

71 This includes the Granger Laws enacted in several Midwest states, including the laws later upheld by the Supreme Court in Munn v. Illinois, 94 U.S. 113 (1877).

72 See Ron Chernow, Titan: The Life of John D. Rockefeller, Sr. (New York: Random House, 1998).

73 S.C.T. Dodd, "The Present Legal Status of the Trusts," Harvard Law Review 7 (1893) 157-158.

74 See, for example, "Chicago's Gas Trust," New York Times, February 4, $1888,2$.

75 William L. Letwin, "Congress and the Sherman Antitrust Law," University of Chicago Law Review 23 (1956): 222 (noting that "between 1888 and 1890 , there were few who doubted that the public hated the trusts fervently").

76 People v. Chicago Gas Trust Co., 130 Ill. 268, 283-287 (1889).

77 State v. Nebraska Distilling Co., 29 Neb. 700 (1890).

78 People v. North River Sugar Refining Co., 121 N.Y. 582 (N.Y. 1890).

79 People v. Chicago Gas Trust Co., 302.

80 Walter Chadwick Noyes, A Treatise on the Law of Intercorporate Relations, 2nd ed. (Boston: Little, Brown, and Company, 1907), §448 (noting several state statutes providing for the forfeiture of corporate charters for antitrust violations). State courts found this to be the case as well. For example, see State v. Boeckler Lumber Co., 206.

${ }^{81}$ Bruce Bringhurst, Antitrust and the Oil Monopoly (Westport, CT: Greenwood Press, 1979), 43.

82 Will Wilson, "The State Antitrust Laws," American Bar Association Journal 47 (1961): 160, 161.

${ }^{83}$ For a good overview of state antitrust laws and the remedies allowed under these statutes written shortly after these laws were enacted, see Arthur Jerome Eddy, The Law of Combinations, Vol. 2 (Chicago: Callaghan and Co., 1901), especially Part VIII.

84 Cong. Rec., 51st Cong., 1st sess., 1890, 21, pt. 3: 2460.

85 Ibid., 2456-2459.

${ }^{86}$ Cong. Rec., 50th Cong., 2nd sess., 1889, 20, pt. 2: 1167.

87 Following the path-breaking Cotton Seed Oil Trust case in Louisiana, for example, the trust simply transferred its assets to Rhode Island. "Trusts in the Courts," New York Times, January 8, 1890, 4.

88 McCurdy, "The Knight Sugar Decision," 322-323.

${ }^{89}$ Cong. Rec., 51st Cong., 1st sess., 1890, 21, pt. 3: 2456, 2460.

90 Ibid., 2457.

91 Bringhurst, Oil Monopoly, 3.

92 For examples of criticism, see "The Government and the Anti-Trust Law," New York Times, June 16, 1892, 4 (arguing the DOJ's Sherman Act litigation has been "farcical from the beginning"); "Sherman for the

Polity, Vol 44, No. 3 (2012): pg. 373-399. DOI. This article is (C) Palgrave Macmillan and permission has been granted for this version to appear in e-Publications@Marquette. Palgrave Macmillan] does not grant permission for this article to be further copied/distributed or hosted elsewhere without the express permission from Palgrave Macmillan. 
NOT THE PUBLISHED VERSION; this is the author's final, peer-reviewed manuscript. The published version may be accessed by following the link in the citation at the bottom of the page.

Trusts," New York Times, October 13, 1892 (arguing the federal government's antitrust actions included "sham indictments").

93156 U.S. 1 (1895).

94 Ibid., 11.

95 Jeremiah W. Jenks, "Review of Chicago Conference on Trusts: Speeches, Debates, Resolutions, by the Civic Federation of Chicago," Political Science Quarterly 15 (1900): 349.

96 Civic Federation of Chicago, Chicago Conference on Trusts (Chicago: The Lakeside Press, 1900), 109, 111, 115.

97 Ibid., 567-568.

98 Ibid., 291-292.

99 Indiana Attorney General, Biennial Report for the Year November 1, 1900 to October 31, 1901 (Indianapolis, 1902), 25, as cited in McCurdy, "The Sugar Knight Decision," 341.

100 For examples of state antitrust prosecutions following enactment antitrust statutes, see "St. Louis Trust Companies," New York Times, Oct. 18, 1897; "Move Against Southern Road," New York Times, Feb. 5, 1901; "Northern Securities Suit in Minnesota," New York Times, Apr. 20, 1902; "Texas Wars on Business," New York Times, Aug. 20, 1903; Queen Insurance Co. v. State, 86 Tex. 250 (1893); State v. Standard Oil, 61 Neb. 28 (1900); State v. Buckeye Pipeline Co., 61 Ohio St. 520 (1900); Hammond Packing Co. v. State, 81 Ark. 519 (1907); State v. Standard Oil, 218 Mo. 349 (1909).

101193 U.S. 197 (1904). Before the United States became involved in prosecuting the case, the suit had originated by action by the Minnesota Governor and SAG. "Gov. Van Sant Takes Action," New York Times, December 19, 1901.

102 "State Attorneys to Petition Congress," New York Times, October 2, 1907; "Would Curb Power of Federal Courts," New York Times, October 1, 1907.

103 These coordinated efforts included those of Tennessee and Missouri. See Bringhurst, Oil Monopoly, chap. 4.

104 For example, in Richardson v. Buhl, 77 Mich. 632 (1889), a private business owner sued a principal of the Diamond Match Company (the "Match Trust"), seeking to enjoin the trust's sale of stock.

105 Horace Gay Wood, A Practical Treatise on the Law of Nuisances in Their Various Forms, 3d. ed. (San Francisco: Bancroft-Whitney Co., 1893), 853.

106 State v. Minnesota Thresher Manufacturing Co., 40 Minn. 213, 214 (1889). For other state court cases restating similar doctrines, see Rice v. National Bank of the Commonwealth, 126 Mass. 300 (1879); Hunt v. Legrand Roller Skating Rink Co., 143 Ill. 118, 121 (1892); State v. Union Investment Co., 7 S.D. 51 (1895); Union Trust Co. of New York

Polity, Vol 44, No. 3 (2012): pg. 373-399. DOI. This article is (C) Palgrave Macmillan and permission has been granted for this version to appear in e-Publications@Marquette. Palgrave Macmillan] does not grant permission for this article to be further copied/distributed or hosted elsewhere without the express permission from Palgrave Macmillan. 
NOT THE PUBLISHED VERSION; this is the author's final, peer-reviewed manuscript. The published version may be accessed by following the link in the citation at the bottom of the page.

v. Atchinson, Topeka \& Santa Fe Railroad Co., 8 N.M. 327 (1895);

State v. Milwaukee Independent Telephone Co., 133 Wis. 588 (1907).

107 Queen Insurance Co. v. State, 22 S.W. 1048, 1052 (Tex. Civ. App. 1893)

(overruled on other grounds by Queen Insurance Co. v. State, 24 S.W. 397 (Tex. 1893))

108 For a good summary when states established the office and its mode of selection, see Lewis W. Morse, "Historical Outline and Bibliography of Attorneys General Reports and Opinions," Law Library Journal 30 (April 1937): 39-247. Also see Myers and Ross, State Attorneys General: Powers and Responsibilities, esp. chapters 1-2.

109 McCurdy, "The Knight Sugar Decision," 321 (1979).

110 "Has No Law Been Broken?" New York Times, February 22, 1888, 4;

"Editorial," New York Times, February 1, 1888, 4. Also see "The Sugar Trust to Be Sued," New York Times, July 2, 1888, 4.

111 "Making a Legal Test," The Washington Post, Jan. 27, 1888, 1; "The St. Louis Gas Trust," New York Times, Feb. 4, 1888, 4; "War On The Oil Monopoly: An Application Made to the Attorney General," New York Times, Mar. 18, 1891; "Can Force Elevated Road Reforms: Lawyers Say the Attorney General Has Full Power," New York Times, Feb. 14, 1903, 2.

112 "Chicago's Gas Trust," New York Times, Feb. 4, 1888, 2; "How to Reach the Trusts," New York Times, Feb. 6, 1888, 4.

113 "Misused Charters," New York Times, January 14, 1890, 4.

114 "Competition and the Law," New York Times, February 28, 1888, 4.

115 Edward M. Thornton, A Treatise on Attorneys at Law (Northport, N.Y.: Edward Thompson Co., 1914), §740.

116 Christensen, "The State Attorney General," 311.

117 Bringhurst, Oil Monopoly, 87.

118 Eugene Lewis, Public Entrepreneurship: Toward a Theory of Bureaucratic Political Power (Bloomington, IN: Indiana University Press, 1980), 1718.

119 Ida M. Tarbell, History of the Standard Oil Company, Vol. 2 (New York: McClure, Phillips, and Company, 1904), 143; Bringhurst, Oil Monopoly, 14.

120 Bringhurst, Oil Monopoly, 12-14.

121 Prominent Republican politician Mark Hanna, for example, suggested to Watson that he was making a major political mistake by prosecuting Standard Oil. Ibid., 14-15.

122 See, for example, "Leave to Sue Granted," New York Times, October 9, 1888 (New York SAG accusing the Sugar Trust of "abuse of its powers"); "Colorado Sues to End Smelter Trust," New York Times, July 1, 1902 (Colorado SAG accusing the Smelter Trust of "violating the laws").

Polity, Vol 44, No. 3 (2012): pg. 373-399. DOI. This article is (C) Palgrave Macmillan and permission has been granted for this version to appear in e-Publications@Marquette. Palgrave Macmillan] does not grant permission for this article to be further copied/distributed or hosted elsewhere without the express permission from Palgrave Macmillan. 
NOT THE PUBLISHED VERSION; this is the author's final, peer-reviewed manuscript. The published version may be accessed by following the link in the citation at the bottom of the page.

123 William Letwin, Law and Economic Policy in America (New York: Random House, 1965), 82-83, fn. 8.

124 "Colorado Sues to End Smelter Trust."

125 State v. Standard Oil Co., 30 N.E. 279 (Ohio 1892). This is not to say that the SAGs always succeeded in de-linking "legal duty" from "mere politics" in such a way. During the late 1890s, Standard Oil made SAGs a frequent target of political organizing, as Watson's (also "activist") successor in Ohio discovered with the corporation's successful campaign to deny his Republican Party renomination in 1899. Bringhurst, Oil Monopoly, 34.

126 My Lexis-Nexis searches suggest that public nuisance litigation declined after the New Deal, which is consistent with other scholarly findings. For example, Donald Gifford notes that public nuisance cases dwindled after the Progressive Era. See note 40.

127 Martha Derthick, Up in Smoke: From Legislation to Litigation in Tobacco Politics (Washington: CQ Press, 2005).

128 See Complaint, Moore ex rel State v. American Tobacco Co., et al, No. 941429 (Miss. Ch. Ct. Jackson County, filed May 23, 1994), Count III. This lawsuit by Mississippi Attorney General Mike Moore was the first state lawsuit filed against the tobacco industry, but eventually the tobacco litigation involved all SAGs, many of whom also incorporated public nuisance claims into their complaints. Gifford, "Mass Products Liability Tort," 759-760.

129 Connecticut v. American Electric Power, No. 04-CV-05669 (S.D.N.Y. 2005). The Supreme Court recently rejected the SAGs' attempt to use federal common law to address climate change, but left open the ability to bring such lawsuits based upon state public nuisance theories. American Electric Power v. Connecticut, 564 U.S. (2011).

130 See W. Kip Viscusi, Regulation through Litigation (Washington D.C.: American Enterprise Institute, 2002).

${ }^{131}$ See Myers and Ross, State Attorneys General: Powers and Responsibilities (2007).

Polity, Vol 44, No. 3 (2012): pg. 373-399. DOI. This article is @ Palgrave Macmillan and permission has been granted for this version to appear in e-Publications@Marquette. Palgrave Macmillan] does not grant permission for this article to be further copied/distributed or hosted elsewhere without the express permission from Palgrave Macmillan. 
Table 1. Quo Warranto Litigation against Corporations, By Region, 18651915

$\begin{array}{ccc}\text { Region } & \text { Number of Cases } & \text { \% of Cases } \\ \text { Northeast } & 60 & 14.9 \% \\ \text { South } & 40 & 9.9 \% \\ \text { Midwest } & 272 & 67.5 \% \\ \text { West } & 31 & 7.7 \%\end{array}$

Source: Author's compilation from searches of the Lexis-Nexis legal database

Table 2. Significant State Attorney General Quo Warranto Litigation Against the Trusts

\begin{tabular}{|c|c|c|c|c|}
\hline State & $\begin{array}{l}\text { SAG } \\
\text { Party }\end{array}$ & Defendant & $\begin{array}{c}\text { Year } \\
\text { Initiated }\end{array}$ & Litigation Result \\
\hline LA & $\mathrm{D}$ & $\begin{array}{l}\text { American Cotton Oil Trust } \\
\text { ("the Cottonseed Trust") }\end{array}$ & 1887 & $\begin{array}{l}\text { Enjoined from } \\
\text { doing business in } \\
\text { state }\end{array}$ \\
\hline NY & $\mathrm{D}$ & $\begin{array}{c}\text { North River Sugar Refining } \\
\text { Company } \\
\text { ("the Sugar Trust") }\end{array}$ & 1888 & Dissolution of trust \\
\hline IL & $\mathrm{R}$ & $\begin{array}{c}\text { Chicago Gas Trust Company } \\
\text { ("the Gas Trust") }\end{array}$ & 1888 & Dissolution of trust \\
\hline CA & $\mathrm{D}$ & $\begin{array}{c}\text { American Sugar Refining } \\
\text { Company } \\
\text { ("the Sugar Trust") }\end{array}$ & 1889 & Dissolution of trust \\
\hline NE & $\mathrm{R}$ & $\begin{array}{c}\text { Nebraska Distilling Company } \\
\text { ("the Whisky Trust") }\end{array}$ & 1890 & Dissolution of trust \\
\hline $\mathrm{OH}$ & $\mathrm{R}$ & $\begin{array}{c}\text { Standard Oil } \\
\text { ("the Oil Trust") }\end{array}$ & 1890 & Ousted from trust \\
\hline IL & $\mathrm{D}$ & $\begin{array}{c}\text { United States School } \\
\text { Furniture Company ("the } \\
\text { Furniture Trust") }\end{array}$ & 1894 & Dissolution of Trust \\
\hline IL & $\mathrm{D}$ & $\begin{array}{c}\text { Distilling and Cattle Feeding } \\
\text { Company } \\
\text { ("the Whisky Trust") }\end{array}$ & 1895 & Dissolution of Trust \\
\hline MO & $\mathrm{D}$ & $\begin{array}{l}\text { Armour Packing Company } \\
\text { ("the Meat-Packing Trust") }\end{array}$ & 1902 & $\begin{array}{l}\text { Ordered to pay } \\
\text { fines and costs }\end{array}$ \\
\hline $\mathrm{CO}$ & Populist & $\begin{array}{l}\text { American Smelting and } \\
\text { Refining Company ("the } \\
\text { Smelter Trust") }\end{array}$ & 1902 & $\begin{array}{l}\text { Dismissed on } \\
\text { procedural grounds }\end{array}$ \\
\hline
\end{tabular}

Source: Author's compilation from searches of the Lexis-Nexis legal database

Polity, Vol 44, No. 3 (2012): pg. 373-399. DOI. This article is (C) Palgrave Macmillan and permission has been granted for this version to appear in e-Publications@Marquette. Palgrave Macmillan] does not grant permission for this article to be further copied/distributed or hosted elsewhere without the express permission from Palgrave Macmillan. 